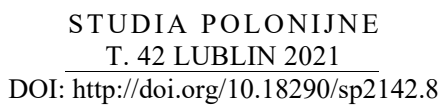

KRYSTYNA ROMANISZYN

\title{
MIGRACJE A STYL ŻYCIA
}

\section{WPROWADZENIE}

Sygnalizowany w tytule związek między mobilnością przestrzenną a stylem życia kieruje uwagę ku kwestii wyborów i dróg życiowych realizowanych za pośrednictwem migracji. Jest to relacja złożona i godna namysłu. W studiach migracyjnych, szczególnie tych dotyczących rejonu Morza Śródziemnego, kwestia mobilności niepodejmowanej ani z przyczyn ekonomicznych, ani politycznych i łączącej się częściowo z turystyką pojawia się w pierwszej dekadzie obecnego stulecia, nieco później, bo u schyłku tej dekady napotykamy w nich określenie lifestyle migration. Dochodzono więc do niego sukcesywnie drogą analiz przede wszystkim mobilności prowadzącej z północy Europy na południe, w rejony śródziemnomorskie. To determinowało sposób rozumienia migracji stylu życia, bo tak możemy tłumaczyć określenie lifestyle migration. Nazywa ono wyróżniony typ, przede wszystkim „śródziemnomorskiej”, mobilności i nie tyle zamyka, ile otwiera problem badawczy dotyczący relacji między mobilnością a tym, co nazywamy stylem życia. Nasuwają się w związku z tym pytania, czy nowej nazwie odpowiada zarówno nowy, jak i nowo odkryty typ migracji? Czy nadano nazwę istniejącemu, lecz nie dostrzeganemu i nie wyszczególnianemu rodzajowi mobilności? Czy wyróżniono i nazwano jeden ze znanych motywów bądź skutków różnych typów migracji uznając go za podstawowy? Z racji złożoności relacji między migracją a stylem życia powyższe pytania można uznać za rozłączne, odpowiedź na jedno z nich nie dezaktualizuje pozostałych. O ich istotności decyduje również ogólniejsza kwestia odpowiedniości między nazwą a jej obiektem, bardzo aktualna w czasach mnożenia bytów pojęciowych, także w dziedzinie studiów migracyjnych.

Prof. dr hab. KRYSTYNA ROMANISZYN - Instytut Socjologii na Uniwersytecie Jagiellońskim w Krakowie; e-mail: krystyna.romaniszyn@uj.edu.pl; ORCID: https://orcid.org/0000-0002-5800-3007. 
Rezultatem tych poczynań naukowych jest gąszcz pojęć o przecinających się lub wręcz tożsamych zakresach znaczeniowych, nieprecyzyjnie definiowanych i pozostawionych bez, zwykle jakiegokolwiek, odniesienia do pojęć już istniejących ${ }^{1}$. Nie wymaga zatem dodatkowego uzasadnienia potrzeba namysłu nad związkiem między mobilnością a stylem życia nieograniczanym do mobilności nazwanej migracją stylu życia. Postawione pytania stanowią punkt wyjścia i wyznaczają kierunek analizy tej kwestii. Rozpoczyna ją ogólna charakterystyka migracji stylu życia poprzedzająca przegląd podstawowych sposobów definiowania pojęcia „styl życia”, zaś zwieńczeniem jest namysł nad typami zależności zachodzącej między stylem życia a mobilnością.

\section{MIGRACJE STYLU ŻYCIA - OGÓLNA CHARAKTERYSTYKA}

Jak wynika z genezy dociekań nad wyróżnionym typem migracji nazwanym migracją stylu życia, bywa on poprzedzany wyjazdami turystycznymi (wypoczynkowymi), które ostatecznie okazują się formą rekonesansu poprzedzającą decyzję o migracji. Jest w tym typie mobilności obecny element, który możemy nazwać porzuceniem, opuszczeniem lub ucieczką od dotychczasowego życia wraz z jego ograniczeniami, by móc zacząć „od nowa”. Może się to łączyć z krytyczną oceną dotychczasowego życia i miejsca, w którym się ono toczyło, a zawsze łączy się z porównywaniem życia i jego warunków przed i po migracji. Migracje stylu życia mogą wynikać z pragnień i marzeń i stanowić ich realizację. W tym typie migracji jest także obecny element projekcji własnego życia i siebie, co oznacza, że ma ona związek z (re)konstrukcją tożsamości pochodną odnalezienia „siebie” i „swojego miejsca" na ziemi. To wszystko sprawia, że migracje stylu życia zdają się więcej mówić o samych migrujących niż o warunkach, w jakich dotychczas żyli. Migracje te mogą być sezonowe lub stałe i w obydwu przypadkach prowadzą do miejsca uznanego za bardziej odpowiednie do bytowania. Ten typ migracji podejmują osoby w różnym wieku, nie jest to mobilność „zarezerwowana" dla jakiejś szczególnej kategorii wiekowej, a jej subiektywne przyczyny są tak zróżnicowane, jak miejsca, ku którym ci migranci zmierzają. Mimo tego możliwe okazało się wyróżnienie kilku odmian migracji stylu życia. Pierwszą jest migracja powodowana pragnieniem lepszego

\footnotetext{
${ }^{1}$ Notabene takie postępowanie przeczy pierwszej zasadzie nauki, jaką jest kumulacja wiedzy, i sprawia, że czynione przy tej okazji deklaracje o wkładzie nowych propozycji do wiedzy zastanej są bezpodstawne.
} 
życia, będącego przeciwieństwem życia prowadzonego przed migracją, drugą stanowi mobilność do miejsc przedstawianych i wyobrażanych sobie jako idylla, trzecia to migracja podejmowana przez osoby lub grupy z kręgów bohemy ${ }^{2}$. Wspólnymi elementami wskazanych odmian omawianego typu migracji są: świadome i celowe, stałe lub sezonowe odejście przez osoby stosunkowo zamożne od prowadzonego dotychczas sposobu życia na rzecz tego wybranego.

Z przedstawionej wyżej ogólnej charakterystyki można wyprowadzić kilka wniosków. Po pierwsze - migracje stylu życia są niedawno rozpoznanym i nazwanym nowym typem mobilności. Stanowią one - po drugie - fenomen ostatnich trzech lub czterech dekad. Po trzecie - ich obiektywnym zapleczem jest wzrost przeciętnej zamożności społeczeństw Północy, łatwość i taniość komunikacji (utrzymywania łączności) oraz przemieszczania się i co za tym idzie - niebywały rozwój turystyki wraz z jej zapleczem reklamowym. Notabene, stały wzrost mobilności w skali całego globu również po części wynika $z$ tych przesłanek. Nie ulega wątpliwości, że warunki, w jakich zaistniał omawiany typ migracji, nie są stałe i dane raz na zawsze, przeciwnie - nie brak współcześnie symptomów wskazujących na nieodległy koniec znanej nam rzeczywistości społeczno-ekonomicznej z jej łatwością i masowością komunikacji i przemieszczeń oraz (względną) zamożnością społeczeństw. Wydaje się nawet, że rzeczywistość ta szybkimi krokami odchodzi w przeszłość, stając się historią wprost na naszych oczach. W takim przypadku migracje stylu życia okażą się tylko jednym z wyróżników czasów przełomu wieków XX i XXI.

Powyższe ustalenia dostarczają twierdzącej odpowiedzi na pierwsze z postawionych na wstępie pytań: nowej nazwie odpowiada nowy i nowo odkryty typ migracji. Jednocześnie pozwalają one na odniesienie się do kwestii zawartej w drugim pytaniu, które dotyczy nadania nazwy istniejącemu wcześniej, a nie wyróżnianemu rodzajowi mobilności. Jak wiadomo, mobilność czasowa, niekiedy sezonowa, krótko- lub długookresowa wynikająca z przyjętego czy obowiązującego w danym środowisku stylu życia bądź też będąca skutkiem poszukiwania, a następnie realizacji swojego stylu życia, miała miejsce w przeszłości, na przykład w dziewiętnastowiecznej Europie. Była ona jednak udziałem wyłącznie stosunkowo wąskiego kręgu, czyli wyższych i zamożnych warstw społecznych oraz artystów. Migracje te nie wiązały się również z odejściem bądź zerwaniem z dotychczasowym życiem, przeciwnie

\footnotetext{
${ }^{2}$ M. BENSON, K. O'REILly, Migration and the search for the better way of life: a critical exploration of life style migration, ,The Sociological Review” 57(2009), no. 4, s. 608-625.
} 
- stanowiły jego integralny element. I to przede wszystkim, a nie ekskluzywność, odróżnia je od współczesnych migracji stylu życia. Nie można zatem uznać, że mimochodem odkryto istniejący już wcześniej typ mobilności, będący wówczas udziałem nielicznych. Wprawdzie obecnie studia migracyjne są de facto, chociaż nie bez wyjątków, ahistoryczne, lecz tym razem nie była to okoliczność ograniczająca poznanie. Puentując, jeśli uwzględnimy perspektywę historyczną, możemy uznać, że dziewiętnastowieczna ekskluzywna mobilność będąca elementem stylu życia wyższych warstw społecznych, jest poprzedniczką zdemokratyzowanych, bo dostępnych dla każdej chętnej i wystarczająco zamożnej osoby migracji stylu życia przełomu wieków XX i XXI. Ujmując zaś rzecz w perspektywie teoretycznej, możemy uznać ekskluzywną mobilność integralnie związaną z prowadzonym stylem życia za historyczny podtyp migracji stylu życia.

Rozłączność postawionych pytań, wynikająca ze złożoności relacji między migracją a stylem życia sprawia, że udzielone już odpowiedzi nie dezaktualizują ostatniego z pytań. Przeciwnie - zawarta w nim kwestia zależności między stylem życia a mobilnością podejmowaną z innych pobudek otwiera kolejny obszar analizy. Tę poprzedza zdefiniowanie kategorii stylu życia.

\section{STYL ŻYCIA - KWESTIE DEFINICYJNE}

Styl życia to pojęcie o wielu znaczeniach. Może ono dotyczyć zwyczajów i postaw, wzorów konsumpcji i zachowań społecznych danej kategorii społecznej, warstwy, klasy lub grupy ${ }^{3}$. Styl życia jest zarówno atrybutem jednostek, jak i wyróżnikiem różnych zbiorowości. Jak ujął to Marian Golka: „styl życia obejmuje cechy i zachowania jednostek czy grup, które są ich swoistym wyborem wynikającym tak z motywów osobistych, jak i społecz-

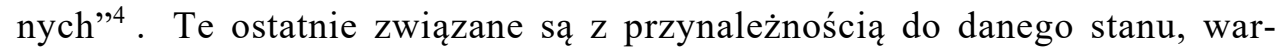
stwy, klasy lub grupy społecznej, bądź aspirowane do nich. W ten sposób stykają się ze sobą analizy poświęcone stratyfikacji społecznej i stylowi życia, o czym dalej. Styl życia możemy pojmować na sposób nominalistyczny, skupiając się w badaniach jednostek bądź grup na ustalaniu syndromu jego cech czy elementów składowych. W takim ujęciu można przyjąć, że w zakresie pojęcia mieszczą się m.in.: poziom i charakter konsumpcji, wygląd

\footnotetext{
${ }^{3}$ Por. Stownik socjologii i nauk społecznych, red. G. Marshall (red. polskiego wydania M. Tabin), Warszawa 2005, s. 369.

${ }^{4}$ M. GolKA, Socjologia kultury, Warszawa 2007, s. 192.
} 
zewnętrzny (głównie ubiór), urządzenie mieszkania, sposób spędzania wolnego czasu, wzory życia rodzinnego, charakter kontaktów społecznych (ich częstotliwość, miejsce, dobór znajomych), zachowania związane z higieną, ochroną zdrowia i rekreacją, poziom i charakter uczestnictwa w kulturze, uznawane, lecz niekoniecznie odczuwane wartości ${ }^{5}$. Styl życia możemy też ujmować całościowo, jako sposób życia odróżniając na przykład jego wariant wiejski od miejskiego ${ }^{6}$. Z obydwoma zaproponowanymi ujęciami stylu życia łączy się ściśle kwestia możliwości wyboru. Styl życia ujmowany na sposób nominalistyczny aktualizuje pytania o jego cechy, determinanty ${ }^{7}$ i możliwość ich kompozycji (wyboru), gdy w ujęciu całościowym skupiamy się na opisie samych jego przejawów przyjmując, że podstawową determinantą jest bytowanie w mieście lub na wsi ${ }^{8}$.

We wspomnianych badaniach społecznej stratyfikacji inspirowanych Weberowskim rozumieniem stanu i klasy społecznej, kategoria stylu życia jest elementem ich definicji, podobnie jak jest ona elementem charakterystyki zawodów. Definiując polską klasę średnią i podejmując jej badanie, Henryk Domański stwierdza: „tym, co identyfikuje członków klasy średniej na co dzień, jest ich wygląd, specyficzny styl w sferze prywatnej i orientacje życiowe", a także sposób spędzania wolnego czasu i podejście do własnego zdrowia przejawiające się $\mathrm{w}$ praktykowaniu zachowań prozdrowotnych ${ }^{9}$. Jednak we współczesnych społeczeństwach, wraz w polskim, przyjęty styl życia manifestowany przez wygląd, zachowania, styl konsumpcji może też wyrażać i wspomagać chęć odróżniania się. W takim przypadku „zanika związek między społeczno-ekonomiczną pozycją jednostki oraz jej stylem życia i konsumpcji, jej tożsamością i politycznymi zachowaniami”" ${ }^{10}$. Tak powstają tzw. subkultury gustu czy alternatywne style bądź sposoby życia

\footnotetext{
${ }^{5}$ Tamże, s. 192-193.

${ }^{6}$ Ten ostatni charakteryzując jako odznaczający się m.in.: wzrostem instrumentalizmu w stosunkach społecznych, osłabieniem znaczenia więzów pokrewieństwa, pluralizmem normatywnym czy sekularyzacją; por. Stownik socjologii i nauk społecznych..., s. 411.

${ }^{7}$ Do takich czynników należą pochodzenie społeczne, wykształcenie, dochody (M. GolKA, Socjologia kultury..., s. 193).

${ }^{8}$ Oczywiście, ten prosty schemat komplikują zachodzące zmiany, w tym przekształcenie wsi w obszary wiejskie łączące się m.in. z migracjami rezydencjalnymi.

${ }^{9}$ H. Domański, Polska klasa średnia, Wrocław 2002, s. 24. Jak autor zauważa, w latach 1990. konsumpcja na pokaz związana ze sposobem zamieszkiwania stanowiła zasadniczy wyróżnik klasy średniej: „Nie wystarcza mieć tylko własny dom. Sygnałem przynależności do klasy średniej jest posiadanie «właściwego» adresu, ponieważ podziały geograficzne w miastach nakładają się na hierarchie klasowe [...] «na warszawskich salonach nie liczy się ten, kto nie mieszka w Konstancinie»" (tamże, s. 38-39).

${ }^{10}$ B. SzaCKA, Wprowadzenie do socjologii, Warszawa 2003, s. 307.
} 
postrzegane zwykle „poprzez wartości i formy konsumpcji”" ${ }^{11}$. Również w polskim społeczeństwie zaszła wyraźna zmiana i jeśli w latach siedemdziesiątych XX wieku wyróżniane style życia - elitarny, neomieszczański, neoplebejski, robotniczy i styl społeczeństwa masowego - wiązały się (jeszcze) ze społeczną stratyfikacją, to współcześnie wyróżnia się także style życia zupełnie od niej oderwane, jak: styl sportowy, alternatywny, ekologiczny, kosmopolityczny, artystyczny, mafijny itp. ${ }^{12}$

Wskazane przemiany polegające na oddzielaniu stylu życia od posiadanej - aktualnie - pozycji społecznej, notabene destabilizowanej przez uelastycznienie rynku pracy i związaną z tym fragmentację karier zawodowych, stanowią wyzwanie badawcze. Także w obszarze studiów migracyjnych, bowiem migracje należy uznać za czynnik współkształtujący zachowania i działania składające się na styl życia migrantów i osób niemobilnych pozostających z nimi w wielorakich relacjach. Rodzi się zatem potrzeba stałego badania:

- udziału migracji w transmisji stylów życia;

- wpływu oczekiwań związanych ze stylem życia na podjęcie i realizację decyzji o migracji, innymi słowy - czy i dla zaspokojenia jakich potrzeb związanych ze stylem życia jest ona podejmowana;

- znaczenia naśladownictwa ${ }^{13} \mathrm{w}$ przyjmowaniu stylu życia przez samych migrantów i osoby niemobilne, lecz utrzymujące z nimi kontakty;

- trwałości, po powrocie, nabytego na emigracji stylu życia i możliwości jego prowadzenia w odmiennym środowisku społeczno-kulturowym;

- stylu życia jako manifestacji tożsamości i jej, ewentualnych, przemian w toku migracji.

Część wyszczególnionych problemów badawczych - wynikających z uznania migracji za ważny czynnik kształtowania zachowań i działań składających się na styl życia osób mobilnych i za ich pośrednictwem także tych niemobilnych - jest poruszana w studiach migracyjnych poświęconych różnym innym wątkom. Wymagającym przedsięwzięciem naukowym, które należy podjąć, jest systematyzacja zgromadzonej wiedzy, zwieńczona jej syntezą. Wspomagającym owo przedsięwzięcie zadaniem możliwym do podjęcia od razu jest wskazanie tropów badawczych. Zadanie to sygnalizuje tytuł niniej-

\footnotetext{
${ }^{11}$ Por. Stownik socjologii i nauk społecznych..., s. 369.

${ }^{12}$ M. GolKa, Socjologia kultury..., s. 194-195.

${ }^{13} \mathrm{Na}$ dostrzeżenie i wykorzystywanie w studiach migracyjnych zasługuje teoria mimetyczna, wskazująca na potężną moc naśladownictwa w relacjach międzyludzkich (A. ROMEJKO, Teoria mimentyczna jako metoda w badaniach polonijnych na przykładzie Wielkiej Brytanii, [w:] W kręgu badań nad Polonia i duszpasterstwem polonijnym, red. S. Zych, B. Walicki, Lublin 2015).
} 
szego artykułu, a dookreśla trzecie z postawionych pytań, dotyczące związku między migrowaniem a stylem życia.

\section{MIGRACJE A STYL ŻYCIA - WZAJEMNA ZALEŻNOŚĆ}

W odwołaniu do wiedzy zastanej z dziedziny studiów migracyjnych można założyć istnienie dwustronnej zależności między migracjami i stylem życia. Innymi słowy, można wskazać na dwa typy tej zależności: pierwszym jest wpływ migracji na styl życia osób mobilnych, drugim - wpływ oczekiwań dotyczących stylu życia na decyzję o migracji. Przy czym druga z wymienionych zależności nie ogranicza się bynajmniej do omówionych uprzednio migracji stylu życia. Udział oczekiwań związanych ze stylem życia dostrzegano $w$ polskiej literaturze przedmiotu w analizach tzw. migracji solidarnościowej, czyli exodusu, który miał miejsce w drugiej połowie lat 1980., u schyłku PRL-u. Pojawiają się w nich propozycje ujmowania tej fali jako migracji związanej w kwestią stylu życia, i to w dwojaki sposób. Po pierwsze dlatego, że część emigrujących motywowała ją dążeniem do prowadzenia pożądanego stylu życia, co było niemożliwe do zrealizowania w PRL-u. Po drugie dlatego, że niektórzy emigranci nawykli do „małej stabilizacji”, czyli stylu życia prowadzonego w latach 1970., decydowali się na wyjazd w ucieczce przed postępującym obniżaniem się poziomu życia w kraju. Jedni i drudzy łączyli decyzję o emigracji ze sprawą poziomu i stylu konsumpcji uważanego za jeden z ważniejszych elementów stylu życia, a nawet $\mathrm{z}$ nim utożsamianego ${ }^{14}$. Fali migracyjnej tamtego czasu nie można jednak uznać za podtyp czy odmianę migracji stylu życia, ponieważ czynnikiem wypychającym z kraju były względy ekonomiczno-polityczne, czyli zniszczenie wielkiego ruchu społecznego, represje wymierzone w jego uczestników oraz katastrofa ekonomiczna dotykająca wszystkich wraz z wynikającym z niej brakiem perspektyw. Tamci migranci byli też niezamożni, a zamożność zamierzali dopiero osiągnąć, dzięki migracji. Omawiany przykład reprezentuje typ migracji hybrydowej, w której motywy polityczne łączą się $\mathrm{z}$ ekonomicznymi, te drugie zaś nie są związane $\mathrm{z}$ brakiem środków do życia, lecz z poziomem życia uznawanym za niezadowalający. $Z$ tego powodu typ ten zasługuje na nazwę: polityczne migracje stylu życia. Nie należy on

${ }^{14} \mathrm{~W}$ literaturze $\mathrm{z}$ zakresu socjologii konsumpcji nie brak definicji stylu życia pojmowanego właśnie jako styl konsumpcji; por. m.in. D. SLATER, Consumer Culture and Modernity, Cambridge 2002 . 
tylko do powojennych dziejów Polski, wiele wskazuje na to, że dominuje we współczesnych falach migracyjnych napierających na kraje UE.

Podążanie na Zachód w celu zdobycia możliwości finansowych dla prowadzenia w Polsce lub poza nią pożądanego stylu życia, wraz z wyższym poziomem konsumpcji, wydaje się stałym wyborem licznych Polaków. Mimo zmian zachodzących po roku 1989, był i jest on nadal podejmowany. W jednym z badań przeprowadzonych w Anglii na początku XXI wieku biorący w nim udział Polacy oświadczyli, że to nie brak pracy w kraju, ale niskie zarobki skłoniły ich do migracji i nie zdecydują się na powrót do pracy gorzej płatnej niż obecna, mimo że ta nie odpowiada ich kwalifikacjom ${ }^{15}$. Oznacza to, że osiągnięty za granicą poziom i styl konsumpcji motywujący do pozostawania na migracji był dla nich ważniejszy od życia zorientowanego na karierę zawodową. Nie jest to argumentacja odosobniona, przeciwnie - liczni Polacy migrowali w ostatnich dekadach, „by żyć i cieszyć się życiem" bez oszczędzania i odkładania gratyfikacji na później ${ }^{16}$. Do wyjazdu motywowało ich pragnienie prowadzenia życia $\mathrm{w}$ innym niż przed wyjazdem stylu, obejmującym styl i poziom konsumpcji. W nieodosobnionych przypadkach była to migracja bez zobowiązań: „nie wynika ona ze sprecyzowanych planów życiowych i odpowiada postawie otwartej na nowe możliwości i aktywnie je kreującej. Taka migracja jest sposobem przeżywania życia, zaspokajaniem potrzeby swobody i nowych wrażeń. Jest projektem otwartym, którego przebieg i zakończenie zostanie napisane przez tok wydarzeń" ${ }^{17}$.

Nowszego przykładu dostarczają wywiady przeprowadzone z Polakami migrującymi do różnych krajów Europy i do Stanów Zjednoczonych ${ }^{18}$. Wynika $\mathrm{z}$ nich, że jednym z istotnych deklarowanych powodów migracji była chęć zmiany sprowadzającej się do zmiany stylu życia pojmowanego jako styl konsumpcji, bo dotyczącej „chęci osiągania poziomu życia dostępnego w krajach zachodnich"19. Młodsi zaś respondenci jako jedną z przyczyn migracji podawali styl życia łączony przez nich z samorealizacją sprowadzającą się do osiągania wyższych zarobków, przewidywalną ścieżką kariery

${ }^{15}$ A. Klimont, Polacy w Wielkiej Brytanii. Studium życia i pracy współczesnych migrantów zarobkowych na przykładzie miasta Stratford-on-Avon, niepublikowana praca magisterska napisana pod moim kierunkiem w Instytucie Socjologii UJ w 2007 r.

${ }^{16}$ K. Romaniszyn, Rzecz o pracy i konsumpcji. Analiza antropologiczna, Kraków 2007, s. 222n.

${ }^{17}$ Tamże, s. 225.

${ }^{18}$ Wywiady zostały przeprowadzone w latach 2011-2013 z polskimi migrantami m.in. do Holandii, Norwegii, Belgii, Stanów Zjednoczonych. J. ISAŃSKI, Migracje i transfery kapitału spotecznego, Poznań 2015.

19 Tamże, s. 163. 
zawodowej, nowymi możliwościami spędzania wolnego czasu, rozwijania zainteresowań i przebywania $\mathrm{w}$ wielonarodowym gronie rówieśników ${ }^{20}$. Podjęli oni migrację w związku z pragnieniem prowadzenia stylu życia odmiennego od dotychczasowego, lecz nie do końca przed wyjazdem sprecyzowanego: „wątek poszukiwania własnego, odmiennego od dotychczasowego stylu życia pojawiał się spontanicznie w większości moich wywiadów"21. Opisana mobilność realizowana jest przez osoby spragnione „nowego początku”, polegającego na zmianie prowadzonego stylu życia na „zachodni”, nie zawsze określony, a mimo to pożądany jako apriorycznie atrakcyjniejszy od dotychczasowego. Można uznać, że mobilność ta konstytuuje podtyp migracji stylu życia. Jest on obecny we współczesnych migracjach z Polski, dotyczy przede wszystkim młodych osób poszukujących swojego miejsca w świecie, których do migracji skłania przede wszystkim chęć prowadzenia życia w „zachodnim" stylu.

W migracjach podejmowanych przede wszystkim z pobudek ekonomicznych można śledzić odwrotną zależność, jest nią wpływ odmiennego otoczenia społeczno-gospodarczego na styl życia migrantów. Interesującym materiałem dającym pewien wgląd $\mathrm{w}$ tę kwestię, i to w perspektywie historycznej, są listy polskich emigrantów do Brazylii i Stanów Zjednoczonych pisane w ostatniej dekadzie XIX wieku ${ }^{22}$. Notabene, materiał ten uświadamia wartość, jaką w badaniach socjologicznych mają dokumenty osobiste ${ }^{23}$. Przegląd zawartości listów nie tylko ujawnia istnienie różnorakich związków między migracją podejmowaną z powodów ekonomicznych a stylem życia, lecz także świadomość tego faktu wyrażaną przez autorów. Jeden z emigrantów do Stanów Zjednoczonych ujmuje to następująco: mnie się lepi zdaje być $w$ Ameryce jak żebym $w$ kraju byt i miat pare morgów ziemi. Bo tu jeżeli mi tylko Bóg zdrowia użyczy to się troszczyć wcale nie potrzebuje, bo tu co zarobie to mi starcza na wyżywienie i pare talarów w kieszeń zostanie każdego miesiaca [...] bo tu kto robi to sobie $i$ zje $i$ wypije i pięknie się ubierze

\footnotetext{
${ }^{20}$ Tamże, s. 160. Atrakcyjną formą spędzania wolnego czasu możliwą dzięki uzyskiwanym zarobkom okazywało się: podjęcie treningów, uczęszczanie na koncerty, możliwość spożycia alkoholu w restauracji (tamże, s. 162).

${ }^{21}$ Tamże, s. 160n.

${ }^{22}$ Listy te ocalałe z pożogi II wojny światowej, zgromadzone w Archiwum Akt Dawnych w Warszawie, dokąd trafiły po przejęciu materiałów carskiej Ochrany, zostały zebrane w zbiorze w opracowaniu W. Kuli, N. Assorodobraj-Kuli, M. Kuli, Listy emigrantów z Brazylii i Stanów Zjednoczonych 1890-1891, Warszawa 1973.

${ }^{23} \mathrm{~W}$ tym kontekście należy wspomnieć o zasługach przedwojennego Instytutu Gospodarstwa Społecznego, działającego przy SGH w Warszawie, dla pozyskiwania i promowania tego rodzaju materiałów.
} 
i grosza do kieszeni uszparuje (list 184). Inny autor w podobny sposób zachwala życie, tym razem, w Brazylii: nie wiem co to jest bieda, życie sobie prowadze królewskie wina mam tyle co $w$ Polsce wody $i$ wódki $i$ wszystkich trunków [...] I donosze wam, co ja zjem potraw w Brazylii, to wy w roku niewidzieliście $i$ w Polsce pomżecie $i$ widzieć nie będziecie. A ziemi tyle mam co chce (list 45). Kolejny emigrant tak opisuje swoje „pańskie” życia w Brazylii: Proszę cię przyjeżḋaj ze swoju żonu i dziećmy do nas, bo jest dobrze, bo ja sobie żyje jak pan $u$ was $w$ Polsce, który posiada kilka folwarków [...] bo ja mam lepi jak dziedzic w Polsce, który ma 10 folwarków (list 44). A dwaj inni konstatują: życie dostajemy dość dobre, że i żaden pan folwarczny tego nie zje i nie widzi w Polsce, że wina mamy jak wody $i$ wódki (list 43), oraz tu $u$ nas sa ludzie teraz przeszło 17 lat, maja majątek jak u was ślachta polska (list 50). Z listu pisanego ze Stanów Zjednoczonych wynika jednak, że jego autor dostrzega i negatywnie ocenia zmianę swojego stylu życia wymuszoną przez tryb podjętej pracy: Bo w kraju to jak sobie chcesz to możesz robić $i$ każda niedziele $i$ każde święto masz spokojne. A tu $w$ Ameryce to nie jest tak, bo tu jak zaczniesz robić to musisz robić dzień i noc i święto i nie święto $i$ każdo niedziele, bo choć byś chciat sobie z dzień odpoczać, to ci nie dadzq jeno musisz prosto tak pracować jak w kraju konie lub woty (list 209). $\mathrm{O}$ zmianie stylu życia w Stanach Zjednoczonych informuje również taka oto lapidarna konstatacja emigrantki: Sa stowiki, kwiaty, ale trzeba iść daleko do ogrodów, a kto za czas zaptaci? (list 203). Dwaj emigranci zwracają uwagę na dylematy związane z warunkami pracy i życia kolidującymi z wiarą, jej nakazami, a także przyjętymi zwyczajami: ksiądz zapowiada [...] że taki który by miat robote stracić przez to święto to nie grzeszy, że pracuje (list 192), oraz: A pościć nikt nie pości tylko w piatek nazywa się post, ale i to ze smalcem księża każa jeść (list 173).

W listach można również wyczytać przywiązanie do wyniesionego z kraju stylu życia i łączących się z nim przekonań. Zdaje z tego relację jeden z emigrantów do Brazylii: $W$ mieście Porto Alegre katolickie księża i biskup wyrobił dla Polaków, że wiency jak tysiąc famili będziemy w jednej osadzie, sami tylko katolicy. W kwietniu mamy mieć w osadzie na pierwszym wstępie najprzód kaplice i kapłana, który będzie nas nauczat po polsku (list 49). A w dwóch listach z Brazylii czytamy: Najprzód witam was w nasz staropolski sposób niech bendzie pochwalony (list 40), oraz a w czasie nabożeństwa na chórze pieśń śpiewali polska starodawna Boże coś Polske (list 64).

$\mathrm{Z}$ dostępnych listów wynika, że część ich autorów - emigrantów do Stanów Zjednoczonych „zaakceptowała miejski styl życia i zdecydowała się na 
pozostanie"24. Emigranci wyjeżdżający na stałe do Brazylii i wywodzący się tak samo z warstwy chłopskiej, mając na miejscu możliwość wyboru wybierali różnie. Jedni w odmiennych wprawdzie warunkach odtwarzali znany sobie sposób i styl życia gospodarując na otrzymanej ziemi, której ilość czasem wprost oszałamiała: Kochana Żuno donoszę ci, że dostałem gruntu bardzo dużo, że nie wiem sam wiele może być włók tego gruntu (list 42). Jak dalej czytamy: $i$ to wszystko sie rodzi co $i$ tu to $i$ w Polsce, kartofle, kapusta, pszenica $i$ żyto jare [...]. Ten czlowiek zarobi, co ze soba weźmie nasiona z Polski, w konkluzji zaś emigrant ten stwierdza: dla nas [...] interes na gruncie, bo $w$ mieście nie ma co robić. Ale pojawiała się też nowa postawa „kolonisty”, a z nią zapewne odmienny po części styl życia: Dziękuję ci Boże żeś pokierowat moje kroki $w$ te strone, a prosze cię tylko o zdrowie to za pomoca boża będę z czasem kolonista (list 40). W listach z Brazylii znajdujemy także świadectwa radykalnego i świadomego odejścia od stylu życia właściwego polskim włościanom, bowiem czytamy w nich: Słowem handle nadzwyczajne, kto ma parę rubli, to może się dobrze wzbogacić na karczmie, bo tam nie ma żadnych patentów (list 74), oraz i mam dostać zapomoge do handlu, bo będę sobie sklep i karczmę zakładać bo można wszystko mieć bez żadnego patentu (list 54), a także to tam można wielki interes zrobić, kto ma pieniadze to wielki interes, bo ja skoro tylko troche do grosza przyjde to zara sobie założe karczme, bo tamo ni ma nijaki (list 43).

$\mathrm{Z}$ zachowanych listów płyną następujące wnioski: po pierwsze - migracja podjęta z przyczyn ekonomicznych łączyła się z wyborem (osadnicy w Brazylii) lub przymusem (robotnicy w Ameryce) dotyczącym przyjętego stylu życia. Po drugie - migracja ta stwarzała możliwość zmiany stylu życia, przez niektórych (z włościanina karczmarz) skwapliwie wykorzystywaną. Po trzecie - migracja $\mathrm{z}$ polskich wsi wynikająca $\mathrm{z}$ pragnienia gospodarowania na roli w kraju dzięki zapracowanym w Ameryce pieniądzom lub w Brazylii na otrzymanej ziemi, prowadziła niektórych do niezamierzonej zamiany stylu życia (dobrowolnej lub przymusowej). Po czwarte - zmiany stylu życia zarysowane w listach zaszły na emigracji, a kwestia ich trwałości po, ewentualnym, powrocie do kraju pozostaje z konieczności otwarta.

Przedstawione materiały pokazują, że migracje podejmowane z przyczyn ekonomicznych nie pozostają bez wpływu na styl życia osób je podejmujących, a wpływ ten może przybierać różne formy - od świadomego potwierdzenia po świadomą i radykalną zmianę dotychczasowego stylu życia. Co

${ }^{24}$ K. RomAnisZyn, Zmiany postaw emigrantów polskich do Brazylii i Stanów Zjednoczonych (1890-1891), „Przegląd Polonijny” 1980, z. 3, s. 64. 
więcej, ta ostatnia może łączyć się z (radosnym) odkryciem możliwości, jakie daje migracja, ściślej - osiągane zarobki i kontakt $\mathrm{z}$ odmiennym otoczeniem społeczno-kulturowym w zakresie prowadzonego stylu życia. Przekonują o tym wypowiedzi tych współczesnych polskich migrantów, z przytaczanych już badań, którzy po przyjeździe poznawali i akceptowali nowy dla nich styl życia: „wielu z nich adaptowało się więc do warunków życia w nowych miejscach, ulegając zastanym w nich normom, a także przyczyniając się do ich przenoszenia wraz z każdymi odwiedzinami w Polsce" ${ }^{25}$. Osoby te nie opuszczały więc Polski dla zmiany stylu życia, lecz go zmienili na nowy już na emigracji pod wpływem otoczenia społeczno-kulturowego. Tej mobilności nie można uznać za migrację stylu życia lub jej następny podtyp, ponieważ zmiana stylu życia jest nieplanowanym rezultatem migracji. Zależność pomiędzy dwiema analizowanymi zmiennymi jest tu odwrotna od omówionej poprzednio, można więc mówić o odmiennym typie tej zależności.

Przykładu nieplanowanej zmiany stylu życia w toku migracji, w rezultacie przebywania w odmiennym środowisku społeczno-kulturowym, dostarczają także badania przeprowadzone w latach 1990. wśród polskich migrantów zarobkowych ${ }^{26}$. Zmiana, o której mowa, dotyczyła sposobów spędzania wolnego czasu. Jedna z Polek mieszkająca od kilku lat w Wiedniu wyznała, że na początku pobytu czas wolny spędzała „na Praterze”, czyli miejscu o charakterze wesołego miasteczka, dopiero później polubiła spacery nad Dunajem i w Stadtparku oraz koncerty (darmowe) przed Ratuszem, inna zaś zasmakowała $\mathrm{w}$ grze w kasynie, gdzie spędzając wolny czas wydawała budżetowe nadwyżki ${ }^{27}$. Gruntowność i trwałość zmiany w stylu życia nie pozostaje bez wpływu na decyzję o powrocie i na rezygnację z kolejnych migracji. Wyraźnie wskazywały na to rozmowy z Polakami mieszkającymi w Grecji. Dla wielu z nich ,piękno przyrody, uroki klimatu [...] a także właściwy gospodarzom styl życia, stają się istotnym czynnikiem wpływającym na decyzję o pozostawaniu, przedłużaniu pobytu" i o powrocie po okresowych pobytach w Polsce ${ }^{28}$. Zmiana, jaka zaszła w stylu życia tych osób, sprzężona $\mathrm{z}$ faktem niemożności jego zachowania w kraju, skutecznie zniechęcała do reemigracji. „Ci z Polaków, którzy mieszkają w Atenach [...] ogromnej kilkumilionowej metropolii, cały rok niemal do brzasku tętniącej życiem i oferującej swoim mieszkańcom styl życia, jakiego dać nie mogą ich rodzinne, na ogół

\footnotetext{
${ }^{25}$ J. ISAŃSKI, Migracje i transfery..., s. 163.

${ }^{26}$ Odwołuję się do badań terenowych, które prowadziłam wśród polskich migrantów w Atenach w 1993 r. i w Wiedniu w 1999 r.

${ }^{27}$ K. RomANISZYN, Kulturowe implikacje międzynarodowych migracji, Lublin 2002, s. 146.

${ }^{28}$ K. Romaniszyn, Polacy w Grecji, ,Studia Polonijne” 16(1994), s. 20.
} 
małe i bardzo małe miejscowości w Polsce", jeśli do nich powracają, to $\mathrm{z}$ niemałym trudem ${ }^{29}$. Ujawniane $\mathrm{w}$ rozmowach zmiany dotyczyły przede wszystkim sposobów spędzania wolnego czasu. Uzyskiwane zarobki pozwalały rozmówcom na: częste odbywanie krajoznawczych wycieczek po Grecji, a niekiedy na dalsze podróże oraz na regularne zabawy w ateńskich tawernach i dyskotekach zapraszających polskich gości. Należy podkreślić, że były to stałe sposoby spędzania wolnego czasu, a przywykli do takiego życia polscy kilkuletni ,ateńczycy” nie byli wręcz zdolni do powrotu do stylu życia swoich rodzinnych miejscowości w kraju. Mimo tak dużego znaczenia omawianej kwestii, nie można uznać tej mobilności za migrację stylu życia, ponieważ inne, czyli ekonomiczne były jej pobudki, a uzyskana względna zamożność oraz idące w ślad za nią nowe możliwości i nawyki spędzania wolnego czasu stały się udziałem tych osób dopiero po kilkuletnim pobycie i pracy w Grecji. Przykłady te natomiast ujawniają siłę i znaczenie wpływu wywieranego przez odmienne otoczenia społeczno-kulturowe na styl życia migrantów. Pokazują one jednocześnie, że nabycie nowego stylu życia przez migrantów długookresowych wiąże się z procesem ich akulturacji, zaś w odniesieniu do osób nieplanujących powrotu może ono być uznane za symptom postępowania procesu asymilacji.

W poszukiwaniu prawidłowości rządzących relacją między migracją a stylem życia warto powrócić do przypadku migracji do Brazylii przełomu XIX i XX wieku, noszącego w literaturze przedmiotu miano „gorączki brazylijskiej”. Jest on ciekawy także dlatego, że niebywałe zainteresowanie wyjazdem do tego kraju w kilku regionach zaboru rosyjskiego i, w mniejszym stopniu, zaboru austriackiego wynikało wprost z zakrojonej na dużą skalę akcji werbunkowej. W jej ramach Brazylia była przedstawiana jako kraj, w którym można otrzymać pod dostatkiem ziemi i prowadzić życie niczym szlachta w kraju. Tak wielki sukces akcji werbunkowej łączył się ściśle z obietnicą dotyczącą stylu życia możliwego do osiągnięcia w Brazylii. Nie jest to też casus odosobniony, przeciwnie - połączenie obietnic dotyczących stylu życia przedstawianego jako atrakcyjny i pożądany z migracją, jest stale wykorzystywanym bodźcem prokurującym mobilność. Także, a może przede wszystkim, współcześnie. Mechanizmem wspomagającym tę działalność jest tworzenie wyobrażeń o dostępności tegoż atrakcyjnego stylu życia w kraju emigracji.

Współczesnego przykładu takich działań, analogicznych co do istoty, chociaż odmiennych co do formy od akcji werbunkowej do Brazylii, dostarczają werbownicy w krajach afrykańskich. O ich aktywności i działaniach

\footnotetext{
${ }^{29}$ Tamże.
} 
czytamy: „Cóż to za dziwne organizacje humanitarne przemierzające Afrykę, nakłaniające młodych ludzi do ucieczki obietnicami lepszego życia w Europie" 30 . Jak konstatowałam: „powstałe na kanwie tych mitów wyobrażenia motywują do migracji w taki sam sposób, jak opowieści XIX- i XX-wiecznych werbowników o «brazylijskim raju» motywowały owładniętych «gorączką brazylijską» mieszkańców polskich wsi. Odmienna pozostaje tylko skala oddziaływania owych kreacji. Ongiś odmierzana krokami werbownika, obecnie nieograniczona dzięki nowym technologiom komunikacji. [...] dostępne za ich pośrednictwem wykreowane obrazy «świata Zachodu» [...] mają swój nader realny udział w decyzji o migracji" ${ }^{31}$. A także w wywoływaniu kolejnych fal masowej emigracji $\mathrm{z}$ tego kontynentu, przy czym same obrazy dobrego życia w kraju docelowym wytworzone i popularyzowane przez ówczesnych i współczesnych werbowników byłyby niewystarczające do wzbudzenia dużych fali migracji. Konieczne są jeszcze inne bodźce. Są nimi konflikty polityczne i militarne, zaś wśród bodźców pokojowych szczególnie ważnymi są: transfer stylów życia i materializm praktyczny. Udział migracji w transmisji stylów życia nie ulega wątpliwości, jest też od dawna przedmiotem uwagi i eksploracji, uprzednio za pomocą pojęcia „dyfuzja”, czyli rozprzestrzeniania się cech kulturowych drogą zapożyczeń, a ostatnio przy użyciu pojęcia „transfery społeczne”. Z ustaleń tych wynika niezbicie, że kontakty pochodne migracjom powrotnym, jak i te wynikające $\mathrm{z}$ udziału w sieciach społecznych budowanych przez osoby mobilne i niemobilne, są wehikułem rozprzestrzeniania się stylów życia przejętych w krajach emigracji.

Wszelako najważniejszym obszarem wymagającym rozległych studiów jest obecnie Internet, a w nim portale społecznościowe, które stały się bodaj najważniejszym miejscem kreowania stylów życia oraz ich „pasem” transmisyjnym. I co najważniejsze, ów „pas” działając ponad granicami, ma moc globalnego oddziaływania. To sprawia, że wirtualne obrazy stylów życia przedstawianych jako pożądane docierają wszędzie wraz ze złudzeniem, że są one do osiągnięcia dla chętnych. Wystarczy dostać się do miejsc, w których „tak się żyje” lub „tak można żyć”. Doprawdy trudno o skuteczniejszą katapultę wyrzucającą fale migracji dla stylu życia wygodniejszego i atrakcyjniejszego od aktualnie prowadzonego i dostępnego ${ }^{32}$. Działa też ona

\footnotetext{
${ }^{30}$ R. SARAH, N. DiAT, Wieczór się zbliża i dzień już się chyli, Warszawa 2019, s. 373.

${ }^{31}$ K. Romaniszyn, W obliczu końca Europy, jaka znamy, „Roczniki Kulturoznawcze” 11(2020), nr 1, s. 27-28.

${ }^{32}$ Niedocenianym aspektem tej mobilności jest konfrontacja stylów życia przybyszów i gospodarzy, której spektakularnym przejawem były wydarzenia, mające miejsce w noc sylwestrową w Kolonii w 2015 r. Zderzenie odmiennych stylów życia towarzyszy i będzie towarzyszyło imigracji
} 
bardzo skutecznie w połączeniu z drugim ze wzmiankowanych bodźców, czyli materializmem praktycznym. Jego znaczenie współcześnie stale rośnie wraz z oczekiwaniem i pożądaniem łatwego życia, w którym szczęście i spełnienie utożsamiane jest $\mathrm{z}$ konsumowaniem kolejnych towarów i wrażeń. Ów materialistyczny hedonizm może być, i bywa, udziałem nie tylko obywateli zamożnych społeczeństw konsumpcyjnych, lecz także mieszkańców niezamożnych krajów i regionów. Owładnięte nim umysły ukierunkowują działania i życie na osiąganie szczęścia rozumianego na sposób materialistyczny, czyli kierują się materializmem praktycznym. Osoby w takim stanie umysłu bez trudu podejmą decyzję o migracji do każdego miejsca, w którym spodziewają się osiągnąć tego rodzaju szczęśliwość. Można powiedzieć, że są one gotowe do migracji, mobilność nie przychodzi im trudno szczególnie wówczas, gdy ukierunkowane są na realizację indywidualnych planów ${ }^{33}$.

Osoby takie istnieją realnie, także w polskim społeczeństwie. Przekonują o tym podawane motywy wyjazdu z kraju, na przykład niektórzy migranci z Podlasia, drugiej dekady XXI wieku, w swej mobilności upatrywali realizacji „indywidualnych szans życiowych”34. Podobnie uzasadniali swoją migrację młodsi respondenci przytaczanych uprzednio badań. Takimi osobami wydają się także migranci spragnieni „zachodniego” stylu życia. Formowaniu ich wszystkich „szczególnie dobrze służy rozwijający się współcześnie kult niczym nieskrępowanego indywidualizmu i wolności od wszelkich zewnętrznych ograniczeń" ${ }^{35}$. Jego skrajnym przejawem jest indywidualizm samorealizacji, zgodnie z którym ,jedynym uzasadnionym motywem postępowania jest miłość własna, poszukiwanie własnej przyjemności, podążanie za własnymi pragnieniami i kierowanie się normami niezależnymi od wpływów zewnętrznych, a odpowiadającymi własnym przekonaniom"36. Upowszechnienie $\mathrm{w}$ społeczeństwie indywidualizmu samorealizacji niweluje wszelkie przeszkody mobilności natury moralnej, takie jak choćby zobowiązania wobec innych. Stąd wiedzie już prosta droga do migrowania dla samorealizacji, która we współczesnych konsumpcyjnych społeczeństwach jest ściśle wiązana

\footnotetext{
skutkującej szybką i masową naturalizacją przybyszów, a tylko w 2019 r. prawa obywatelskie nadano w państwach UE niemal 707 tys. azylantów pochodzących z Afryki, Bliskiego Wschodu i Azji.

${ }^{33}$ K. Romaniszyn, Migracje a zmiana celowa, ,Studia Polonijne” 40(2019), s. 21.

${ }^{34}$ B. CIEŚLIŃSKA, Emigracje bliskie i dalekie, Białystok 2012, s. 167.

${ }^{35}$ K. RoMANiszyn, Migracje a zmiana celowa ..., s. 21.

${ }^{36}$ Z. BOKSZAŃSKI, Indywidualizm a zmiana społeczna, Warszawa 2007, s. 54, 57. „Osoby takie nie biorą się znikąd, przeciwnie biorą się z socjalizacji w społeczeństwie, w którym istotne obszary życia społecznego od edukacji i rynku pracy poczynając, są «adresowane» do jednostki, co zmusza «do 'samotworzenia się’ jednostek jako indywiduów»" (tamże, s. 65).
} 
z poziomem i stylem konsumpcji, jako konstytutywnym elementem stylu życia. Samorealizacja, również tak pojmowana, bywa jednak otwartym projektem i, co z tym idzie, procesem, a nie jednorazowym czy jednofazowym aktem. Włączenie w ten projekt mobilności oznacza, że jednorazowe przemieszczenie może okazać się niewystarczające, co może prowadzić do mobilności jako stylu życia. Ale pod warunkiem, że będzie na nią miejsce w planach globalnych decydentów, których zdolności sprawcze zdają się systematycznie rosnąć, czego jednym z przejawów wydają się polityczne migracje stylu życia szturmujące obecnie kraje UE.

Przedstawiona w niniejszym szkicu dwustronna zależność, czy też dwojaki typ zależności, między migracją a stylem życia jest niezaprzeczalna. W każdym $\mathrm{z}$ obydwóch typów tej zależności można było także wyróżnić typy mobilności. Ich przedstawiony wykaz nie jest zapewne zamknięty, co sprawia, że badanie relacji między migracją a stylem życia winno na stałe zagościć w studiach migracyjnych. Na koniec należy zapytać jeszcze o udział motywacji związanych ze stylem życia w migracjach wewnętrznych. Podejmując tę kwestię na przykładzie Polski, można odwołać się do ogólnopolskiego sondażu na temat preferencji Polaków w zakresie migracji wewnętrznych przeprowadzonego w $2010 \mathrm{r}$. Wprawdzie w badaniach nie uwzględniono kategorii stylu życia, lecz kwestia ta zdaje się być obecna w deklaracjach respondentów. Odpowiedzi na pytanie o preferowany kierunek migracji pokazują zmianę w porównaniu z poprzednimi dwiema dekadami: „niewątpliwie nastąpiła znacząca zmiana w percepcji wsi. Obecnie więcej niż jedna czwarta osób chcących zmienić miejsce pobytu chciałaby zamieszkać na wsi”, drugim wybieranym kierunkiem były duże miasta, „częściej wskazywane jako preferowane miejsca zamieszkania" ${ }^{37}$. Pomiędzy tymi dwoma biegunami lokują się mniejsze miasta „rzadziej niż kilkanaście lat temu wskazywane jako preferowane miejsca zamieszkania”, których mieszkańcy ponadto „częściej niż innych typów miejscowości, wyrażają gotowość do migracji" ${ }^{38}$.

Można przypuszczać, że zebrane deklaracje pozostają w ścisłym związku ze stylem życia, który osoby te chciałyby prowadzić. Pośrednio zdaje się to potwierdzać podawane wyjaśnienie: „zdecydowana większość badanych wskazujących wieś jako preferowane miejsce zamieszkania (85\%) uzasadniała swój wybór bardziej sprzyjającym środowiskiem"39.

\footnotetext{
${ }^{37}$ CBOS, Raport z badań Mobilność i preferencje migracyjne Polaków, Warszawa 2010, s. 8.

${ }^{38}$ Tamże.

${ }^{39}$ Tamże.
} 
Wiele mówiąca jest też korelacja między opiniami a wiekiem: badani „poniżej 45 roku życia częściej niż starsi wybierają duże miasta jako najbardziej dla nich atrakcyjne. Natomiast osoby starsze (w wieku 45 lat i więcej) częściej preferują wieś" ${ }^{40}$. Ci pierwsi w dużych miastach szukaliby zapewne atrakcyjnej, także finansowo, pracy i ucieczki od życia w małym mieście, gdzie „nic się nie dzieje”. Ci drudzy mogą pragnąć ucieczki od „ciekawego życia" w wielkim mieście do środowiska spokojnego i pod wieloma względami przyjaznego. Uzupełnieniem i potwierdzeniem wyników powyższych badań sondażowych są późniejsze ustalenia, wskazujące na pięć najbardziej atrakcyjnych aglomeracji w kraju - stołeczną, wrocławską, krakowską, poznańską i trójmiejską - oferujących „najbardziej atrakcyjne warunki pracy, rozwoju osobistego i kariery", przyciągających szczególnie osoby w młodym wieku ${ }^{41}$. Przeciwnie, „decyzję o przeniesieniu się poza duże miasto podejmują ci, którzy mają już ustabilizowaną sytuację rodzinną i zawodową", co wynika z chęci „poprawy warunków mieszkaniowych (dom jednorodzinny zamiast mieszkania) oraz środowiskowych (mniejsze uciążliwości życia niż w zatłoczonym mieście)"42. Również w tej analizie kategoria stylu życia nie została uwzględniona, można jednak przyjąć, że o atrakcyjności pięciu aglomeracji, $\mathrm{z}$ jednej i przemieszczeniach rezydencjalnych z dużych miast $\mathrm{z}$ drugiej strony, (współ)decydują wiązane $\mathrm{z}$ nimi możliwości prowadzenia pożądanego stylu życia.

Interesujące $\mathrm{z}$ naszego punktu widzenia są też najnowsze badania przeprowadzone wśród młodzieży maturalnej województwa dolnośląskiego ${ }^{43}$. Potwierdzają one niezmienną moc przyciągania wskazanych pięciu aglomeracji dla osób kończących szkoły średnie, pochodzących z małych miast i wsi. Wprawdzie bezpośrednim celem, i podawanym uzasadnieniem, migracji jest kontynuowanie nauki na uczelniach, jednak nie są one „migracjami czasowymi, służącymi zdobywaniu wykształcenia, lecz migracjami trwałymi - już w zamiarze definitywnymi” i kierują się „nie do najbliższych ośrodków

\footnotetext{
${ }^{40}$ Tamże.

${ }^{41}$ P. ŚLESZYŃSKI, Współczesne migracje wewnętrzne w Polsce, [w:] 25 wykładów o migracjach, red. M. Lesińska, M. Okólski, Warszawa 2018, s. 239. „Zazwyczaj mechanizm jest taki, że młoda osoba wyjeżdża na studia do jednego z większych ośrodków, a po ich ukończeniu próbuje «zakorzenić» się w nowym miejscu zamieszkania przez podjęcie pracy i wynajęcie mieszkania (rzadziej jego zakup)" (tamże).

${ }^{42}$ Tamże, s. 244.

${ }^{43}$ Migracje pomaturalne $w$ województwie dolnoślaskim wobec depopulacji regionu $i$ wymogów zrównoważonego rozwoju społeczno-gospodarczego, red. A. Dolińska, R. Jończy, P. Śleszyński, Wrocław 2020.
} 
akademickich, lecz do dużych ośrodków regionalnych (w województwie dolnośląskim - do Wrocławia)" ${ }^{\text {"4 }}$.

Oprócz względów bytowych i materialnych, na które wprost wskazuje $42,2 \%$ badanych ${ }^{45}$, ważne są z pewnością kwestie związane ze stylem życia i konsumpcji. Za wnioskiem takim przemawia i to, że wśród deklarujących zamiar migracji więcej było kobiet niż mężczyzn, co zdaniem autorów wynika z silniejszej niż u mężczyzn chęci „kobiet do poprawy warunków życia, które na peryferiach, zwłaszcza $\mathrm{w}$ zakresie dostępu do pracy $\mathrm{i}$ infrastruktury, je dyskryminują" 46 . Również w tych badaniach nie uwzględniono kategorii stylu życia, można jednak przyjąć, że obranie kierunku „na najbliższą aglomerację" wiąże się z pragnieniem prowadzenia stylu życia, które oferuje wielkie miasto. Jego cenionym przez kobiety elementem - oprócz samorealizacji w sferze zawodowej i niezależności finansowej - może być też „chodzenie na wysokich obcasach" na co dzień, w małych miastach i na wsi nieprzyjęte. Dodatkowe i konieczne badania, które należy podjąć, powinny dotyczyć kreowanych i upowszechnianych w mediach obrazów życia „na prowincji”, czyli na wsi i w małych miastach, oraz życia wielkomiejskiego. $\mathrm{Na}$ weryfikację zasługuje hipoteza, zgodnie z którą w przedstawieniach tych życie polskich prowincjonalnych miasteczek i wsi ukazywane jako nudne i beznadziejne jest przeciwstawiane wspaniałemu wielkomiejskiemu światu, dającemu nieograniczone możliwości rozwoju i zabawy. Zbadanie pod wskazanym kątem przekazu medialnego z pewnością pomogłoby w wyjaśnianiu przyczyn exodusu młodych, w przeważającej liczbie kobiet, z małych miejscowości do polskich aglomeracji.

W świetle przedstawionej argumentacji uprawniony wydaje się wniosek, że również $\mathrm{w}$ migracjach wewnętrznych istotna jest - i zasługuje na uwzględnienie w badaniach - motywacja związana ze stylem życia. Wstępnie można przyjąć, że migracje rezydencjalne łączące się m.in. z przejściem na emeryturę czy porzuceniem pracy w mieście na rzecz samozatrudnienia, także we własnym gospodarstwie rolnym, motywowane pragnieniem wolniejszego tempa życia, niższych kosztów utrzymania, spokoju, ciszy, bliskości przyrody, oraz liczne migracje maturzystów z małych miejscowości do polskich aglomeracji, mają ścisły związek ze stylem życia, jakie osoby te chcą prowadzić.

44 Tamże, s. 166

45 Uzasadniając zamiar opuszczenia miejsca zamieszkania, 42,2\% badanych wskazało na „chęć poprawy sytuacji materialnej i/lub warunków życia własnych lub rodziny” (tamże, s. 161).

46 Tamże, s. 95. Doprecyzowując, autorzy wskazują na niedobór w tych miejscowościach stanowisk pracy w administracji i usługach, które zwykle obsadzane są przez kobiety, i brak infrastruktury społecznej, czyli żłobków, przedszkoli, świetlic. 
Drogą zaś do obranego celu i miejsca jest mobilność przestrzenna, co oznacza, że obok zewnętrznych mamy też wewnętrzne migracje stylu życia. Pozostającym do zbadania problemem pozostaje, czy w przemieszczeniach rezydencjalnych $\mathrm{z}$ jednej i migracji do dużych miast $\mathrm{z}$ drugiej strony chodzi o styl życia ujmowany na sposób całościowy, jako sposób życia odpowiednio wiejski i miejski? Czy też chodzi o styl życia pojmowany na sposób nominalistyczny, jako syndrom dowolnie skomponowanych elementów dotyczących m.in. sposobów spędzania wolnego czasu, w tym uczestnictwa w kulturze, czy charakteru kontaktów społecznych, w tym swobodnego doboru znajomych?

\section{PODSUMOWANIE}

Przeprowadzona analiza pokazuje wyraźną dwustronną zależność między migracją a stylem życia. Obok mobilności podejmowanej celem zmiany stylu życia jako jednego typu tej zależności, mamy drugi jego typ, którym są migracje podejmowane z innych pobudek, lecz skutkujące taką zmianą. W każdym z dwóch typów zależności pojawiają się też rozmaite typy mobilności. W pierwszym $\mathrm{z}$ wymienionych typów zależności mamy zewnętrzne oraz wewnętrzne migracje stylu życia, a podtypem tych pierwszych są migracje wynikające z niedookreślonego pragnienia „nowego początku na Zachodzie”. Na wyodrębnienie zasługują ponadto polityczne migracje stylu życia. Wyrazem drugiego typu zależności jest zmiana stylu życia jako rezultat, a nie cel, migracji. Może ona być wymuszona przez okoliczności zewnętrzne, na przykład tryb pracy, bądź przyjęta ochotnie. Tę pierwszą można dopisać do kosztów migracji, ta druga może pomnażać jej zyski. Niezależnie, czy wymuszone, czy ochotne przyjęcie nowego stylu życia można uznać za wyraz akulturacji bądź wskaźnik procesu asymilacji imigrantów. Jak widać, zależność między dwiema omawianymi zmiennymi nie ogranicza się do migracji stylu życia. Niniejszy szkic nie zamyka też, lecz otwiera rozległy obszar badawczy, jakim są wzajemne powiązania migracji i stylu życia, ich wielorakie przejawy i skutki.

\section{BIBLIOGRAFIA}

Benson M., O'Reilly K., Migration and the search for the better way of life: a critical exploration of life style migration, „The Sociological Review” 57(2009), no. 4, s. 608-625.

BoKSZAŃSKI Z., Indywidualizm a zmiana społeczna, Warszawa: Wydawnictwo Naukowe PWN 2007. 
CBOS, Raport z badań „Mobilność i preferencje migracyjne Polaków”, Warszawa 2010.

CIEŚLIŃSKA B., Emigracje bliskie i dalekie, Białystok: Wydawnictwo UwB 2012.

DOMAŃSKI H., Polska klasa średnia, Wrocław: Wydawnictwo Naukowe UMK 2002.

GolKA M., Socjologia kultury, Warszawa: Wydawnictwo Naukowe Scholar 2007.

ISAŃSKI J., Migracje i transfery kapitału społecznego, Poznań: Wydawnictwo Naukowe UAM 2015.

Kula W., Assorodobraj-Kula N., Kula M. (oprac.), Listy emigrantów z Brazylii i Stanów Zjednoczonych 1890-1891, Warszawa: Ludowa Spółdzielnia Wydawnicza 1973.

Migracje pomaturalne w województwie dolnośląskim wobec depopulacji regionu i wymogów zrównoważonego rozwoju społeczno-gospodarczego, red. A. Dolińska, R. Jończy, P. Śleszyński, Wrocław: Wydawnictwo UE 2020.

RomANISZYN K., W obliczu końca Europy, jaką znamy, „Roczniki Kulturoznawcze” 11(2020), nr 1, s. 17-41.

Romaniszyn K., Migracje a zmiana celowa, „Studia Polonijne” 40(2019), s. 5-32.

ROMANISZYN K., Rzecz o pracy i konsumpcji. Analiza antropologiczna, Kraków: Zakład Wydawniczy Nomos 2007.

ROMANISZYN K., Kulturowe implikacje międzynarodowych migracji, Lublin: KUL 2002.

Romaniszyn K., Polacy w Grecji, „Studia Polonijne” 16(1994), s. 7-98.

ROMANISZYN K., Zmiany postaw emigrantów polskich do Brazylii i Stanów Zjednoczonych (1890-1891), „Przegląd Polonijny” 1980, z. 3, s. 51-64.

RomeJKo A., Teoria mimetyczna jako metoda w badaniach polonijnych na przykładzie Wielkiej Brytanii, [w:] W kręgu badań nad Polonią i duszpasterstwem polonijnym, red. S. Zych, B. Walicki, (Biblioteka Polonii t. XXXIX), Lublin: Ośrodek Badań nad Polonią i Duszpasterstwem Polonijnym; Miejska i Gminna Biblioteka Publiczna w Sokołowie 2015.

SARAh R., Diat N., Wieczór się zbliża i dzień już się chyli, Warszawa: Wydawnictwo SS. Loretanek 2019.

Slater D., Consumer Culture and Modernity, Cambridge: Polity Press 2002.

Słownik socjologii i nauk społecznych, red. G. Marshall (red. polskiego wydania M. Tabin), Warszawa: Wydawnictwo Naukowe PWN 2005.

SzACKa B., Wprowadzenie do socjologii, Warszawa: Oficyna Naukowa 2003.

ŚLESZYŃSKI P., Współczesne migracje wewnętrzne w Polsce, [w:] 25 wykładów o migracjach, red. M. Lesińska, M. Okólski, Warszawa: Wydawnictwo Naukowe Scholar 2018.

\section{MIGRACJE A STYL ŻYCIA}

\section{Streszczenie}

Przedmiotem artykułu jest kwestia zależności zachodzących między mobilnością przestrzenną a stylem życia. Prowadzoną analizę rozpoczyna omówienie specyficznego typu migracji, nazwanego w literaturze przedmiotu migracjami stylu życia (life style migrations). Następnie wskazana i omówiona została dwustronna zależność między obydwiema zmiennymi, czyli udział pożądanego i oczekiwanego stylu życia w podjęciu decyzji o migracji oraz niezakładany przez osoby mobilne, niemniej faktyczny wpływ migracji na przemiany przyjmowanego przez nich stylu życia. W artykule wykorzystane zostały zarówno dane empiryczne pochodzące z badań prowadzonych 
w okresie ostatnich trzech dekad, jak i historyczne materiały biograficzne pochodzące z przełomu XIX i XX wieku.

Słowa kluczowe: migracje; styl życia; migracje stylu życia

\section{LIFE STYLE AND MIGRATION}

\section{Summary}

The paper aims at discussing relations between spatial mobility and life style. The discussion begins with the presentation of life style migrations. It focuses however, on interdependence between both analyzed categories, that is: on life style expectations as one of the pushing factor in migrations decision, and on life style change as an unexpected result of migration. The empirical basis of the presented analysis builds upon data obtained from migration researches curried out in the last decades and from biographical material dated back to XIX and XX centuries.

Keywords: migrations; life style; life style migrations 